DOI: https://doi.org/10.24127/ajpm.v9i4.3114

\title{
PENGEMBANGAN MEDIA E-LEARNING BERBASIS EDMODO PADA MATERI TEOREMA PYTHAGORAS
}

\author{
Farman $^{1 *}$, Chairuddin ${ }^{2}$ \\ ${ }^{1 *, 2}$ Universitas Sembilanbelas November Kolaka, Kolaka, Indonesia \\ *Corresponding author \\ E-mail: $\quad$ farman.math@yahoo.co.id ${ }^{1 *}$ \\ chairuddin.spd@gmail.com $^{2)}$
}

Received 28 September 2020; Received in revised form 10 December 2020; Accepted 19 December 2020

\begin{abstract}
Abstrak
Penelitian ini bertujuan untuk menyusun dan memperoleh media e-learning berbasis edmodo pada materi pythagoras yang valid, praktis dan efektif bagi peserta didik kelas VIII SMP-TQ Muadz Bin Jabal Kendari. Pembelajaran matematika berbasis e-learning menggunakan edmodo dipilih sebagai media alternatif dalam meningkatkan minat dan hasil belajar pada materi pythagoras. Pengembangan e-learning ini dikembangkan dengan model ADDIE yang terdiri atas beberapa langkah, yaitu: (1) analysis (2) design (3) development, (4) implementation dan (5) evaluation. Subyek uji coba dalam penelitian pengembangan ini adalah peserta didik Kelas VIII SMP Mu'adz Bin Jabal Kendari pada Tahun Ajaran 2019/2020 yang berjumlah 31 peserta didik.Uji kevalidan media pembelajaran digunakan lembar validasi dan untuk menguji keefektifan media pembelajaran digunakan angket respon peserta didik. Sedangkan uji keefektifan media pembelajaran digunakan tes hasil belajar materi teorema pythagoras. Berdasarkan penilaian oleh ahli dan pelaksanaan uji coba, diperoleh hasil bahwa media e-learning berbasis edmodo materi teorema Pythagoras memenuhi kriteria valid, praktis dan efektif. E-learning berbasis edmodo dapat dimanfaatkan untuk meningkatkan minat dan memfasilitasi pembelajaran interaktif yang mendukung pemahaman peserta didik SMP Kelas VIII pada materi Pythagoras.
\end{abstract}

Kata kunci: Edmodo; media; e-learning; teorema Pythagoras.

\begin{abstract}
This study aims to compile and obtain edmodo-based e-learning media on pythagorean material which is valid, practical, and effective for grade VIII students of SMP-TQ Muadz Bin Jabal Kendari. E-learning based mathematics learning using edmodo was chosen as an alternative media in increasing interest and learning outcomes of Pythagorean material. This e-learning development is developed with the ADDIE model, which consists of several steps, namely: (1) analysis, (2) design, (3) development, (4) implementation, and (5) evaluation. The subjects in this development research were 31 students of grade VIII SMP Mu'adz Bin Jabal Kendari in the 2019/2020 academic year. The learning media's validity test used a validation sheet, and to test the effectiveness used student response questionnaire. At the same time, the test of the learning media's effectiveness used the learning outcomes test of the Pythagorean theorem. The experts' assessment and the implementation of trials found that the mathematics learning media of the Edmodo-based Pythagorean theorem met the valid, practical, and effective criteria. Edmodo-based e-learning can be used to increase interest and facilitate interactive learning that supports the understanding of grade VIII junior high school students on the pythagorean theorem material.
\end{abstract}

Keywords: Edmodo; media; e-learning; Pythagorean theorem.

This is an open access article under the Creative Commons Attribution 4.0 International License 


\section{PENDAHULUAN}

Perkembangan teknologi informasi dan komunikasi di era revolusi industri 4.0 telah mempengaruhi semua aspek kehidupan. Penggunaan teknologi dalam pendidikan atau produk dari integrasi teknologi informasi ke dalam dunia pendidikan disebut dengan $e$ learning. E-learning adalah semua teknologi yang digunakan untuk mendukung upaya pembelajaran melalui internet. Rusman (2012) menyatakan bahwa suasana e-learning akan memberikan peran yang lebih aktif bagi peserta didik dalam belajar. Melalui e-learning, pendidikan dapat dilakukan dimanapun dan kapanpun.

Namun fenomena di lapangan pemanfaatan teknologi internet dalam pembelajaran belum optimal dimana masih sedikit sekolah yang memanfaatkan internet sebagai media pembelajaran. Kenyataanya sebagian besar sekolah-sekolah telah memiliki jaringan internet dan peserta didik telah mahir dalam menggunakan internet pada berbagai jejaring sosial baik dengan gadget atau laptop. Banyak hal yang menyebabkan terjadinya kondisi tersebut, salah satunya disebabkan kebanyakan guru belum menguasai teknologi internet. Selain itu, belum tersedianya secara utuh media pembelajaran e-learning yang dapat dimanfaatkan peserta didik secara optimal.

Pembelajaran yang kurang memaksimalkan penggunaan media pembelajaran dapat mengurangi minat dan peran peserta didik dalam pembelajaran. Hasil wawancara dengan guru SMP-TQ Muadz Bin Jabal Kendari diperoleh informasi bahwa pembelajaran di kelas dilaksanakan dengan menggunakan powerpoint dan penggunaannya secara offline sehingga siswa tidak bisa mengakses kembali pelajaran melalui internet. Hal ini menjadi menjadi suatu masalah bagi siswa yang duduk jauh dari tampilan proyektor dimana sajian materi ditayangkan melalui powerpoint. $E$ learning dapat menjadi solusi hal tersebut, guru dapat menempatkan materi pada tempat tertentu untuk diakses melalui internet oleh siswa. Selain itu, sebagian besar minat dan motivasi belajar peserta didik pada mata pelajaran matematika masih rendah. Minat yang rendah ini menyebabkan kebanyakan peserta didik mengalami kesulitan dalam menyelesaikan masalah matematika. Hal ini tentunya berimplementasi pada rendahnya pemahaman materi dan hasil belajar matematika peserta didik, salah satunya teorema pythagoras.

Pythagoras merupakan materi geometri yang penerapannya dalam pembelajaran masih memberikan banyak permasalahan dan kesulitan bagi peserta didik dan guru (Sunzuma \& Maharaj, 2019). Permasalahan dan kesulitan yang sering dilakukan oleh peserta didik diantaranya ketika menerapkan konsep teorema pythagoras dalam menyelesaikan permasalahan (Sulistyorini, 2018). Peserta didik juga mengalami kesulitan dalam memahami definisi, menggambarkan simbol atau notasi objek matematika, dan menafsirkan objek matematika dalam bentuk prosedur dalam penyelesaian pertanyaan teorema pythagoras (Rudi et al., 2020).

Mencermati fenomena tersebut, maka diperlukan adanya pemanfaatan media secara maksimal dalam pembelajaran. Penggunaan e-learning pada media belajar online dapat mengatasi masalah efisiensi waktu dan tempat yang sering dihadapi oleh peserta didik. E-learning merupakan model pembelajaran berbasis teknologi 
informasi dan komunikasi yang memberika perubahan budaya belajar dalam konteks pembelajarannya (Sodiq, 2019). Hadi \& Rulviana (2018) menyatakan bahwa dalam melaksanakan e-learning diperlukan suatu media atau yang lebih dikenal dengan sebutan platform untuk menunjang kegiatan e-learning itu sendiri. Salah satu platform yang dapat dimanfaatkan dalam proses pembelajaran e-learning adalah edmodo.

Edmodo merupakan suatu aplikasi berbasis web yang dapat diakses dan dimanfaatkan dalam pembelajaran secara online serta dilengkapi berbagai fitur seperti penyajian materi, forum diskusi, evaluasi dan penilaian (Rahmawati, 2016). Melalui pembelajaran dengan menggunakan edmodo dapat meningkatkan perhatian peserta didik dan memberikan sikap yang lebih positif terhadap belajar online (Alqahtani, 2019). Kong (Susanti, 2018) menyatakan bahwa edmodo efektif dalam pengembangan pedagogis yang sesuai dengan dasar teoritis pembelajaran.

Beberapa penelitian terhadap penggunaan edmodo dalam pembelajaran matematika menunjukkan dampak yang positif. Pemahaman peserta didik sekolah dasar pada materi kubus dan balok melalui pembelajaran dengan edmodo berada dalam kategori baik (Ariani et al., 2017). Media pembelajaran dengan menggunakan edmodo memberi efek pada peningkatan tingkat pemikiran probabilistik peserta didik (Sujadi et al., 2017). Penggunaan edmodo dalam pembelajaran matematika ekonomi lebih baik dibandingkan dengan pembelajaran tanpa menggunakan edmodo dalam peningkatan kemampuan komunikasi (Nasrullah, 2017). $E$ - learning berbasis edmodo memiliki pengaruh yang signifikan terhadap minat, kemandirian, dan hasil belajar matematika (Hatip \& Listiana, 2019). Pendekatan PMRI berbantuan edmodo meningkatkan kemampuan literasi matematika peserta didik secara signifikan dan memiliki kategori yang sangat baik dalam menyelesaikan soal PISA (Wardono et al., 2016).

Urgensi dilakukan penelitian ini karena media pembelajaran matematika berbasis e-learning dalam beberapa penelitian yang sudah ada, belum ada pengembangan media e-learning pada materi Pythagoras. Penelitian ini akan dikembangkan materi melalui media pembelajaran secara online (e-learning) dengan menggunakan edmodo. Kondisi akhir yang diharapkan dengan $e$ learning berbasis edmodo pada materi pythagoras adalah meningkatnya minat, persepsi positif peserta didik dalam belajar matematika dan meningkatnya pemahaman serta hasil belajar matematika pada materi pythagoras.

Penelitian ini bertujuan untuk memperoleh media e-learning berbasis edmodo pada materi pythagoras yang valid, praktis dan efektif bagi peserta didik kelas VIII.

\section{METODE PENELITIAN}

Penelitian ini merupakan penelitian pengembangan media $e$ learning berbasis edmodo yang dapat menciptakan suatu komunitas pembelajaran dalam meningkatkan kemampuan pemahaman materi pythagoras.

Pengembangan desain media pembelajaran dengan pendekatan yang sistematis adalah model ADDIE (Hopkins, 2012). Langkah-langkah pengembangan desain ini terdiri atas(1) analysis yaitu analisis perlu adanya pengembangan e-learning berbasis 
edmodo. Hal ini dilakukan melalui kegiatan observasi kondisi peserta didik dan proses pembelajaran di sekolah serta telaah konsep dan teori yang relevan dengan pengembangan media, (2) design yaitu merancang media $e$ learning berbasis edmodo yang akan dikembangkan dan instrumen penilaian media pembelajaran, (3) development, yaitu dikembangkan e-learning berbasis edmodo dan kemudian edmodo yang dikembangkan diuji validitasnya, merevisi dengan mendesain ulang media pembelajaran dari saran yang diberikan oleh ahli/validator, (4) implementation yaitu penggunaan (uji coba) media e-learning berbasis edmodo dalam suatu aktivitas pembelajaran dan (5) evaluation yaitu mengevaluasi sejauhmana media dapat digunakan sesuai tujuan yang ingin dicapai sehingga diperoleh media yang berkualitas baik. Tujuan evaluasi adalah untuk menilai kualitas kevalidan, kepraktisan dan keefektifan e-learning berbasis edmodo yang diujicobakan.

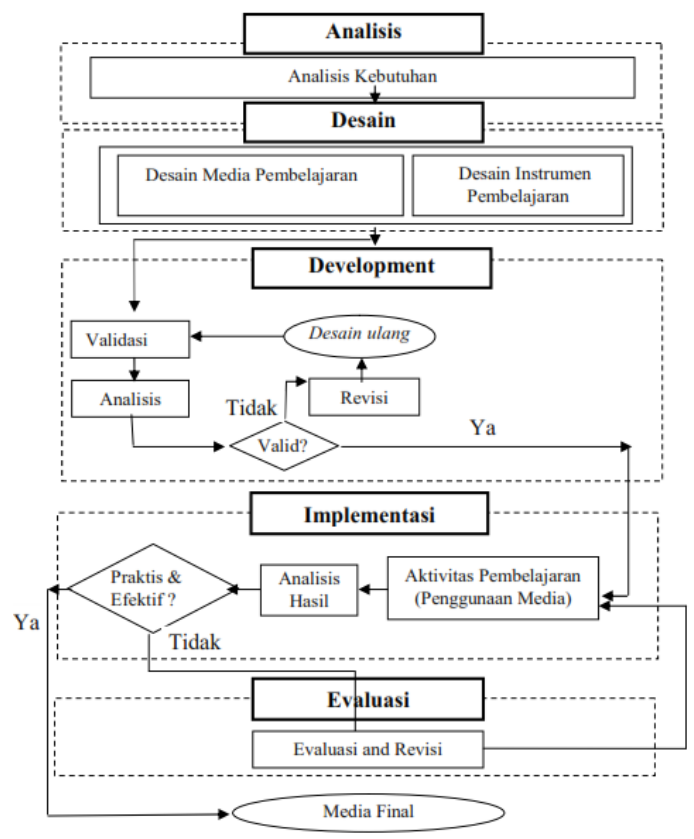

Gambar 1. Prosedur penelitian.
Subyek uji coba dalam penelitian pengembangan ini adalah peserta didik Kelas VIII SMP Mu'adz Bin Jabal Kendari pada Tahun Ajaran 2019/2020 yang berjumlah 31 peserta didik.

Instrumen pengumpulan data yang digunakan dalam penelitian ini terdiri dari lembar validasi yang digunakan untuk mengetahui kevalidan media pembelajaran, angket digunakan untuk memeperoleh informasi kepraktisan media pembelajaran dan tes hasil belajar materi teorema pythagoras digunakan untuk mengetahui keefektifan dari media pembelajaran.

Analisis data kevalidan desain media pembelajaran dilakukan untuk menilai apakah media telah menenuhi kriteria valid. Analisis data dilakukan dengan mencari rata-rata total penilaian validator melalui rata-rata tiap kriteria dan rata-rata tiap aspek pada lembar validasi. Rata-rata total penilaian validator kemudian disesuaikan dengan kriteria kevalidan (Tabel 1) yang ditetapkan (Farman, 2020).

Tabel 1. Kriteria kevalidan produk.

\begin{tabular}{cc}
\hline Interval & Kriteria \\
\hline $4 \leq V R \leq 5$ & Sangat Valid \\
$3 \leq V R<4$ & Valid \\
$2 \leq V R<3$ & Kurang Valid \\
$1 \leq V R<2$ & Tidak Valid
\end{tabular}

Analisis data kepraktisan diperoleh melalui angket respon peserta didik yang mengukur pendapat peserta didik terhadap media pembelajaran yang digunakan. Data hasil angket respon peserta didik berupa skor dianalisis dengan langkah-langkah (1) merekap skor setiap peserta didik, (2) mengkonversi skor rata-rata tiap peserta didik kedalam skala $0-100, \overline{\mathrm{S}_{1}}$, (3) menghitung skor rata-rata untuk seluruh responden $\overline{\mathrm{S}}$, dan (4) membuat kesimpulan berdasarkan kriteria yaitu 
respon positif jika $\bar{S}>50$ atau respon negatif jika $\bar{S} \leq 50$. Media pembelajaran dikategorikan praktis, jika respon kelas positif.

Analisis data keefektifan desain diukur melalui tes hasil belajar dan minat belajar peserta didik setelah media pembelajaran matematika berbasis e-learning dengan menggunakan edmodo diterapkan dalam kegiatan pembelajaran. Langkahlangkah yang digunakan untuk menganalisis hasil minat belajar yaitu menjumlahkan skor dari semua indikator, menghitung skor rata-rata indikator minat belajar peserta didik dan membuat kesimpulan dari hasil analisis yang disesuaikan dengan kriteria yang disajikan pada Tabel 2 .

Tabel 2. Kriteria Minat Belajar

\begin{tabular}{cc}
\hline Interval & Kriteria \\
\hline $85 \leq S R \leq 100$ & Sangat Tinggi \\
$70 \leq S R<85$ & Tinggi \\
$55 \leq S R<70$ & Sedang \\
$40 \leq S R<55$ & Rendah \\
$0 \leq S R<40$ & Sangat Rendah \\
\hline
\end{tabular}

Media pembelajaran dikategorikan efektif jika ketuntasan klasikal tercapai (minimal $75 \%$ peserta didik mencapai nilai 70) dan minat belajar siswa tinggi atau sangat tinggi (Saman et al., 2019).

\section{HASIL DAN PEMBAHASAN}

Pengembangan media e-learning berbasis edmodo pada materi pythagoras dilakukan melalui langkahlangkah pengembangan desain ADDIE. 1. Analisis

Langkah analisis dilakukan melalui observasi kelas dan diskusi bersama guru matematika kelas VIII SMP TQ Muadz Bin Jabal Kendari. Hasil wawancara dengan guru diperoleh informasi bahwa sebagian besar minat belajar peserta didik pada mata pelajaran matematika masih rendah. Minat yang rendah ini menyebabkan peserta didik kurang tertarik dan mengalami kesulitan dalam menyelesaikan masalah matematika, salah satunya teorema Pythagoras.

Dalam kegiatan pembelajaran guru telah berupaya memfasilitasi peserta didik dengan menggunakan model dan metode pembelajaran yang bervariasi diantaranya belajar kelompok, diskusi, ceramah dan tanya jawab. Sedangkan penggunaan media pembelajaran dilakukan dengan mengidentifikasi sumber pendukung pembelajaran matematika pada kelas VIII SMP yaitu berupa buku paket matematika SMP Kurikulum 2013 kelas VIII. Oleh karena itu untuk mendukung tujuan pembelajaran dan mengatasi permasalahan minat dan hasil belajar materi pythagoras, perlu mengkonversi materi dan kompetensi yang ingin dicapai peserta didik dalam suatu media sehingga memudahkan peserta didik dalam melaksanakan aktivitas pembelajaran.

Media yang digunakan dalam pengembangan ini adalah aplikasi edmodo. Fitur utama edmodo adalah fitur online learning material dan online evaluation. Dengan demikian, pilihan yang tersedia di menu dapat membantu proses belajar mengajar dan mengubah kondisi belajar peserta didik menjadi lebih komprehensif, holistik, dan lengkap. Beberapa kelebihan edmodo diantaranya mirip facebook sehingga mudah digunakan, closed group collaboration (grup tertutup dimana peserta didik dapat mengikuti kelas dengan kode yang diberikan), tersedia dalam perangkat smartphone (android dan iphone), dapat diakses kapanpun dan dimanapun, terdapat notifikasi, dan fitur badge yang dapat dimanfaatkan 
untuk meningkatkan motivasi peserta didik (Rahmawati, 2016).

2. Desain

Pada langkah ini dilakukan penyiapan materi Pythagoras yang terdiri dari mencari kebenaran Pythagoras, penerapan konsep Pythagoras, jenis segitiga dan tripel Pythagoras. Materi yang telah disiapkan kemudian disusun dalam bentuk file pdf, PowerPoint, gambar dan video. Penyusunan materi dalam bentuk video disusun dengan menggunakan powerpoint dan aplikasi camtasia. Penggunaan media video dalam menjelaskan materi memiliki pengaruh pada aktivitas pembelajaran di kelas dan berguna dalam meningkatkan hasil belajar siswa (Nasrum \& Herlina, 2019).

Setelah materi telah siap kemudian didesain akun grup edmodo dengan nama "Kelas PYTHAGORAS". Seluruh materi kemudian disimpan pada library (perpustakaan) grup edmodo, sehingga akan memudahkan guru dalam membagikan materi pada peserta didik. Selain materi, juga telah disediakan soal latihan, kuis dan evaluasi akhir. Tampilan desain media e-learning berbasis edmodo materi pytagoras disajikan pada Gambar 2 dan Gambar 3.

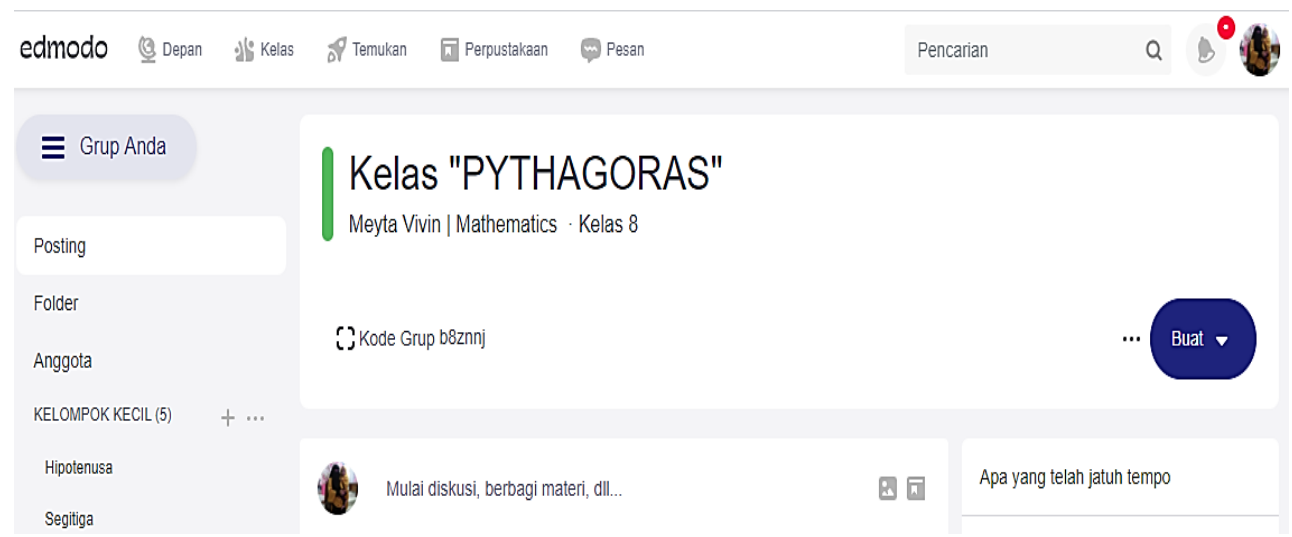

Gambar 2. Tampilan desain beranda.

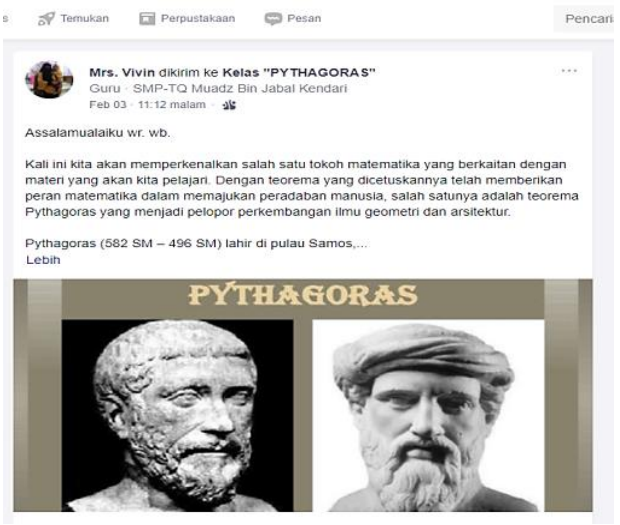

(a)

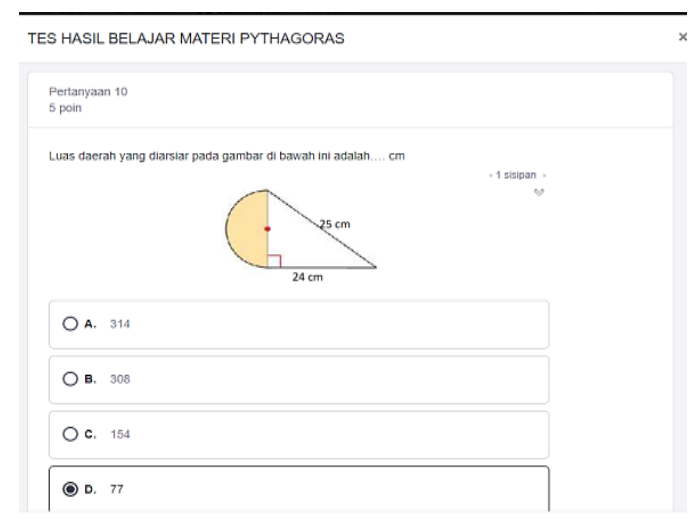

(b)

Gambar 3. Tampilan desain (a) postingan dan (b) tes hasil belajar

Selain desain media, juga di desain instrumen penilaian media pembelajaran. Instrumen yang disusun meliputi (1) lembar validasi (2) angket respon peserta didik terhadap media, (3) 
tes hasil belajar materi pythagoras dan (4) minat belajar peserta didik.

\section{Development}

Rancangan media yang telah disusun pada langkah desain divalidasi oleh tiga validator. Proses validasi dilakukan dengan menyerahkan perangkat dan instrumen serta lembar validasi pada validator. Validator menilai berdasarkan kriteria pada lembar validasi. Hasil validasi dipaparkan pada Tabel 3.

Tabel 3. Hasil validasi produk.

\begin{tabular}{lcc}
\hline Aspek Penilaian & Rerata & Kategori \\
\hline RPP & 4,07 & Sangat \\
Valid \\
Panduan Edmodo & 3,89 & Valid \\
Media pembelajaran & 4,13 & Sangat \\
berbasis Edmodo & & Valid \\
Angket Respon & 4,37 & Sangat \\
Peserta didik & & Valid \\
Tes Hasil Belajar & 4,27 & Sangat \\
Materi Pythagoras & & Valid \\
Angket Minat Belajar & 3,96 & Valid \\
\hline
\end{tabular}

Berdasarkan Tabel 3 hasil penilaian media dan instrumen menunjukkan hasil yang valid dan sangat valid sehingga desain media $e$ learning berbasis edmodo pada materi pythagoras yang dikembangkan layak digunakan pada tahap uji coba lapangan. Pada kegiatan penilaian media dan instrumen, validator juga memberikan saran-saran yang dituliskan pada lembar validasi. Saran-saran tersebut menjadi dasar untuk merevisi sebagai bahan penyempunaan atas kekurangan dalam media, perangkat dan instrumen sebelum tahap implementasi.

\section{Implementasi}

Setelah diperoleh media $e$ learning berbasis edmodo materi Pythagoras yang valid, kemudian dilakukan tahap implementasi media tersebut dalam pembelajaran di kelas. Penggunaan media ini dilakukan sebanyak empat kali pertemuan dengan sub pokok pembahasan mencari kebenaran Pythagoras, penerapan konsep Pythagoras, serta jenis segitiga dan tripel Pythagoras.

Dalam implementasinya, media pembelajaran berupa aplikasi edmodo digunakan di dalam kelas dan di luar kelas (rumah). Setelah peserta didik mendaftar pada aplikasi edmodo dan begabung dalam grup Kelas Pythagoras, guru kemudian membagikan indikator dan tujuan pembelajaran serta materi pembelajaran berupa file pdf, gambar, slide show ppt dan video pada setiap tiga hari sebelum pelaksanaan pembelajaran di kelas. Materi yang telah dibagikan tersebut dapat dipelajari pada saat pembelajaran berlangsung di kelasataupun sebelum atau sesudah pembelajaran di kelas. Namun dalam pembelajaran ini, guru senantiasa mengupayakan dan memfasilitasi peserta didik dengan menginformasikan untuk mempelajarinya sebelum kegiatan pembelajaran di kelas. Pada kegiatan di kelas setelah peserta didik mempelajari materi, peserta didik dibentukkelompok untuk mendiskusikan permasalahan materi Pythagoras yang diberikan pada aplikasi edmodo. Setelah menyelesaikan soal materi Pythagoras kemudian kelompok mengumpulkan jawabanpada kolom komentar soal grup edmodo. Setelah mengumpulkan jawaban kemudian diperiksa jawaban masingmasing kelompok dengan diskusi kelas dan presentasi di depan kelas.

Setelah kegiatan pertemuan untuk materi Pythagoras selesai, pertemuan selanjutnya dilakukan evaluasi pembelajaran materi Pythagoras. Kegiatan evaluasi dilaksanakan selama 2 x 40 menit melalui aplikasi edmodo. Pada langkah ini juga dilakukan pemberian angket respon peserta didik terhadap penggunaan media 
pembelajaran yang dikembangkan dan angket minat belajar siswa.

Analisis respon peserta didik terhadap penggunaan media ditinjau dari aspek rasa senang, keingintahuan, keaktifan, perhatian, dan ketertarikan. Hasil analisis respon peserta didik disajikan pada Tabel 4.

Tabel 4. Hasil respon peserta didik.

\begin{tabular}{ccc}
\hline $\begin{array}{c}\text { Respon } \\
\text { Kelas }\end{array}$ & $\begin{array}{c}\text { Jumlah peserta } \\
\text { didik }\end{array}$ & Rerata \\
\cline { 2 - 3 } & 31 & 70,2 \\
\hline
\end{tabular}

Tabel 4 menunjukkan bahwa rerata respon kelas peserta didik terhadap media pembelajaran adalah 70,2 dan berada pada kategori positif (lebih besar dari 50). Hal ini berarti pengembangan e-learning memenuhi kriteria praktis.

Berdasarkan analisis data hasil belajar peserta didik materi Pythagoras diperoleh rata-rata 73,03 dan jumlah peserta didik yang mencapai nilai 70 sebanyak 24 peserta didik (77\%). Secara ringkas hasil belajar materi Pythagoras disajikan pada Tabel 5.

Tabel 5.Hasil belajar materi Pythagoras.

\begin{tabular}{lc}
\hline \multicolumn{1}{c}{ Hasil Belajar } & Skor \\
\hline NilaiTertinggi & 91 \\
NilaiTerendah & 39 \\
Rerata & 73,03 \\
Persentase ketuntasan & $77 \%$ \\
\hline
\end{tabular}

Tabel 6. Hasil minat belajar.

\begin{tabular}{lcc}
\hline \multicolumn{1}{c}{ Indikator } & Skor & Kategori \\
\hline Perasaan senang & 78,1 & Tinggi \\
Ketertarikan siswa & 77,1 & Tinggi \\
Keterlibatan siswa & 88,1 & Sangat \\
Rajin dalam belajar & 79,4 & Tinggi \\
$\begin{array}{l}\text { Tekun dan disiplin } \\
\text { dalam belajar }\end{array}$ & 78,1 & Tinggi \\
\hline \multicolumn{1}{c}{ Rata-rata } & 80,1 & Tinggi \\
\hline
\end{tabular}

Analisis minat belajar matematika berdasarkan indikatornya disajikan pada Tabel 6 yang menunjukkan bahwa semua indikator minat belajar menunjukkan kategori tinggi. Rata-rata minat belajar siswa dalam kelas adalah 80,1 , artinya respon kelas atas minat belajar terhadap e-learning menggunakan edmodo adalah tinggi.

\section{Evaluasi}

Pada penggunaan awal media $e$ learning berbasis edmodo materi pythagoras masih terdapat beberapa peserta didik yang belum memahami dalam pengumpulan tugas dan melaksanakan kuis, sehingga peserta didik tersebut terlambat mengumpulkan tugas dan mengerjakan kuis. Namun pada pertemuan berikutnya peserta didik telah mampu dan terbiasa menggunakan aplikasi edmodo dengan baik.

Hasil analisis data media pembelajaran materi pythagoras menggunakan edmodo secara ringkas disajikan pada Tabel 7.

Tabel 7. Rekapitulasi pengembangan media E-learning berbasis Edmodo materi Pythagoras.

\begin{tabular}{lc}
\hline \multicolumn{1}{c}{ Hasil } & Kategori \\
\hline $\begin{array}{l}\text { Desain media, instrumen dan } \\
\text { perangkat valid }\end{array}$ & Valid \\
$\begin{array}{l}\text { Respon peserta didik positif } \\
77 \% \text { peserta didik mencapai }\end{array}$ & \\
nilai 70 dan minat belajar & Efektif \\
peserta didik tinggi & \\
\hline
\end{tabular}

Berdasarkan Tabel 7, maka diperoleh suatu kesimpulan bahwa pengembangan media pembelajaran matematika materi teorema pythagoras berbasis edmodo memenuhi kriteria valid, praktis, dan efektif.

Produk e-learning berbasis edmodo materi teorema Pythagoras yang telah diimplementasikan masih 
memiliki beberapa kekurangan yang harus diperbaiki. Kekurangan ini diperoleh melalui hasil diskusi dengan guru dan peserta didik terkait materi dalam video maupun penulisan soal tugas, kuis dan evaluasi yang keliru dalam media. Oleh karena itu produk perlu direvisi untuk disempurnakan. Hasil produk yang telah disempurnakan terdiri dari empat subpokok bahasan yaitu mencari kebenaran Pythagoras, penerapan konsep Pythagoras, jenis segitiga dan tripel Pythagoras. Masingmasing subpokok pembahasan memuat (1) pengantar, (2) materi dalam bentuk file, video dan gambar, (3) Soal latihan, (4) kuis dan (5) Soal tugas. Produk media e-learning berbasis edmodo materi pythagoras yang telah disempurnakan diletakkan pada perpustaakaan aplikasi edmodo seperti pada Gambar 4.

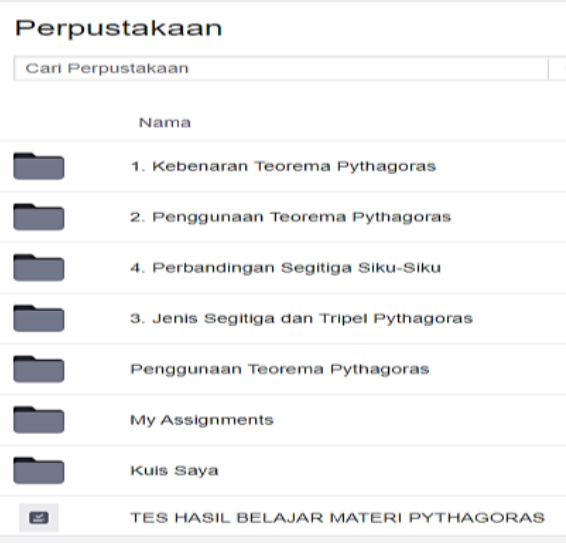

Gambar 4. Perpustakaan materi Pythagoras.

Penggunaan media pembelajaran dalam matematika dapat digunakan sebagai materi suplemen untuk memahami konsep matematika. Kegiatan pembelajaran berbasis media juga memungkinkan untuk mengatasi permasalahan peserta didik dalam memahami materi yang disajikan oleh guru (Wahyudi et al., 2019) dan memudahkan peserta didik dalam menerima pelajaran dan merangsang aktivitas belajarnya (Wardono et al.,
2016). Sama halnya dengan media yang dikembangkan dalam penelitian ini berupa media e-learning berbasis edmodo dapat digunakan sebagai suplemen untuk mencapai tujuan pembelajaran yang diinginkan. Penggunaan e-learning berbasis edmodo dapat memungkinkan peserta didik untuk mengakses sumber belajar di luar kelas, dan memberdayakan pembelajaran yang berpusat pada peserta didik. Selain itu, edmodo dapat membantu keterlibatan peserta didik dalam belajar yang pada dasarnya dicapai melalui berbagai tugas dan lingkungan belajar yang sesuai (Mokhtar, 2018). Meskipun demikian peran guru tetap diperlukan dalam proses pembelajaran karena peran guru tidak dapat sepenuhnya digantikan oleh teknologi.

Media e-learning berbasis edmodo dapat meningkatkan minat belajar peserta didik terhadap matematika. Melalui e-learning, peserta didik memiliki perasaan yang senang, tertarik, rajin, tekun dan disiplin dalam belajar. Hal ini sejalan dengan penelitian Alqahtani (2019) dan Trisniawati et al., (2019) menyatakan bahwa pembelajaran dengan menggunakan edmodo dapat meningkatkan minat dan perhatian peserta didik. Pratama \& Ismiyati (2019) mengungkapkan bahwa melalui penggunaan edmodo dapat memberikan sikap positif siswa terhadap matematika. Selain itu, media $e$ learning berbasis edmodo juga dapat meningkatkan hasil belajar matematika, khususnya materi pythagoras. Hal ini sejalan dengan hasil penelitian Hatip \& Listiana (2019) bahwa e-learning berbasis edmodo memiliki pengaruh yang signifikan terhadap hasil belajar matematika. 


\section{KESIMPULAN DAN SARAN}

Berdasarkan hasil analisis disimpulkan bahwa produk media $e$ learning berbasis edmodo materi teorema pythagoras memenuhi kriteria valid, praktis, dan efektif. Media pembelajaran berbasis e-learning dengan menggunakan edmodo dapat digunakan dalam pembelajaran di kelas untuk memotivasi dan memfasilitasi pembelajaran interaktif yang mendukung pemahaman siswa terhadap konsep teorema Pythagoras.

Produk yang dikembangkan dapat digunakan sebagai materi suplemen dalam pembelajaran di kelas sesuai dengan karakteristik dan manfaat yang ingin dicapai bagi peserta didik Pengembangan media ini hanya menyajikan materi Pythagoras sehingga kedepannya dapat dikembangkan untuk materi lain yang sesuai dengan tujuan pembelajaran yang diharapkan.

\section{UCAPAN TERIMAKASIH}

Ucapan terima kasih kepada Direktorat Riset dan Pengabdian Masyarakat Direktorat Jenderal Penguatan Riset dan Pengembangan Kemenristek/BRIN yang telah memberikan dana penelitian melalui skema Penelitian Dosen Pemula (PDP) Tahun 2020.

\section{DAFTAR PUSTAKA}

Alqahtani, A. (2019). The Use of Edmodo: Its Impact on Learning and Students' Attitudes Toward It. Journal of Information Technology Education: Research, 18, 319-330.

Ariani, Y., Helsa, Y., Ahmad, S., \& Prahmana, R. (2017). Edmodo Social Learning Network for Elementary School Mathematics Learning. Journal of Physics: Conference Series, 943, 012056.
Farman. (2020). Development of Mathematics Learning Design through Problem Posing Approach for Developing Mathematical Reasoning Ability. Proceeding of USN Kolaka-ADRI International Conference on Sustainable Coastal - Community Development (pp.167-174). Kolaka: Universitas Sembilanbelas November Kolaka.

Hadi, F. R., \& Rulviana, V. (2018). Analisis Proses Pembelajaran ELearning Berbasis Edmodo pada Mata Kuliah Geometri. Jurnal Bidang Pendidikan Dasar, 2(1), 63.

Hatip, A., \& Listiana, Y. (2019). Minat, Kemandirian, dan Hasil Belajar Mahasiswa Pendidikan Matematika Dalam E-Learning Berbasis Edmodo. AKSIOMA: Jurnal Program Studi Pendidikan Matematika, 8(3).

Hopkins. (2012). Instructional Design for E-learning: A Guide for The Global Learning Center. Budapest: UNHCR GLC.

Mokhtar, F. A. (2018). Breaking Barriers Through Edmodo: A Qualitative Approach on the Perceptions of University of Malaya Undergraduates. Online Learning, 22(1).

Nasrullah, A. (2017). Efektivitas Penggunaan Media Edmodo Pada Pembelajaran Matematika Ekonomi Terhadap Komunikasi Matematis. Symmetry, Pasundan Journal of Research in Mathematics Learning and Education 2(1), 10.

Nasrum, A., \& Herlina, H. (2019). Developing of Calculus Teaching Materials Based on 
DOI: https://doi.org/10.24127/ajpm.v9i4.3114

Audiovisual. Infinity Journal, 8(2), 209-218.

Pratama, R. A., \& Ismiyati, N. (2019). Pembelajaran Berbasis Edmodo Pada Mahasiswa Pendidikan Matematika Universitas Balikpapan. AKSIOMA: Jurnal Program Studi Pendidikan Matematika, 8(2), 298.

Rahmawati, I. (2016). P Pelatihan Dan Pengembangan Pendidikan Jarak Jauh Berbasis Digital Class Platform Edmodo. Prosiding Temu Ilmiah Nasional Guru (TING) VIII UT, 9.

Rudi, R., Suryadi, D., \& Rosjanuardi, R. (2020). Identifying Students' Difficulties In Understanding And Applying Pythagorean Theorem With An OntoSemiotic Approach. MaPan, $8(1), 1-18$.

Rusman. (2012). Model-Model Pembelajaran Mengembangkan Profesionalisme Guru (Edisi Kedua). Raja Grafindo Persada.

Saman, Ma'rufi, \& Tiro. (2019). Pengembangan Video Pembelajaran Matematika Dalam Meningkatkan Minat dan Prestasi Belajar Siswa pada Materi Persamaan Linear Dua Variabel. Pedagogy: Jurnal Pendidikan Matematika, 4(1), 12.

Sodiq, A. (2019). Pemanfaatan Teknologi Informasi Dan Komunikasi Sebagai Media Pembelajaran. Civic-Culture: Jurnal Ilmu Pendidikan PKN Dan Sosial Budaya, 2(1), 13.

Sujadi, I., Kurniasih, R., \& Subanti, S. (2017). The effectiveness of learning material with Edmodo to enhance the level of student's probabilistic thinking. 040005. https://doi.org/10.1063/1.4983943
Sulistyorini, Y. (2018). Error Analysis in Solving Geometry Problem on Pseudo-Thinking's Students. Proceedings of the University of Muhammadiyah Malang's 1st International Conference of Mathematics Education (INCOMED2017). (pp.103-107). Malang: Universitas Muhammadiyah Malang.

Sunzuma, G., \& Maharaj, A. (2019). Inservice Teachers' Geometry Content Knowledge: Implications for how Geometry is Taught in Teacher Training Institutions. International Electronic Journal of Mathematics Education, 15(1).

Susanti, R. D. (2018). Penerapan Edmodo Pada Pemberian Tes Formatif Mahasiswa Pendidikan Profesi Guru Matematika. AKSIOMA: Jurnal Program Studi Pendidikan Matematika, $7(2), 8$.

Trisniawati, Muanifah, M. T., Widodo, S. A., \& Ardiyaningrum, M. (2019). Effect of Edmodo towards interests in mathematics learning. Journal of Physics: Conference Series, 1188, 012103.

Wahyudi, W., Ambarwati, M., \& Indarini, E. (2019). Development Of Web Game Learning Materials For Primary School Students. Infinity Journal, 8(2), 199-208.

Wardono, Waluya, S. B., Mariani, S., \& Candra D, S. (2016). Mathematics Literacy on Problem Based Learning with Indonesian Realistic Mathematics Education Approach Assisted E-Learning Edmodo. Journal of Physics: Conference Series, 693, 012014. 